INTERNATIONAL JOURNAL OF MULTIDISCIPLINARY RESEARCH AND ANALYSis

ISSN(print): 2643-9840, ISSN(online): 2643-9875

Volume 05 Issue 01 January 2022

DOI: 10.47191/ijmra/v5-i1-17, Impact Factor: 6.072

Page No.- 128-132

\title{
Relationship of Arm Muscle Strength, Arm Muscle Endurance, Abdominal Strength and Balance with Arrow Achievement
}

\author{
Gagah Nurya Putra ${ }^{1}$, M. Furqon Hidayatullah ${ }^{2}$, Sapta Kunta Purnama ${ }^{3}$ \\ 1,2,3 Postgraduate in Sports Science, Sebelas Maret University, Indonesia
}

\begin{abstract}
This study aims to determine: To determine the significant relationship between arm muscle strength, arm muscle endurance, abdominal muscle strength and balance on archery achievement. This study uses the correlation method. Determination of the sample using purposive sampling technique, namely 13 archery athletes in Surakarta. The variables of this study consisted of four independent variables, namely arm muscle strength, arm muscle endurance, abdominal muscle strength and balance. The dependent variable is archery achievement. The data of this study were obtained through tests and measurements. The data analysis technique used correlation analysis with normality, linearity, and hypothesis testing, namely correlation analysis. The results showed that there was a significant relationship between arm muscle strength, arm muscle endurance, abdominal muscle strength, and balance and archery achievement, with an $\mathrm{R}$ value of 0.921 . These results indicate that there is a perfect category relationship between arm muscle strength (X1), arm muscle endurance (X2), abdominal muscle strength (X3) and balance (X4) on archery achievement (Y). The results of this study indicate that arm muscle strength, arm muscle endurance, abdominal muscle strength and balance have a significant relationship with archery achievement. It can be concluded that arm muscle strength, arm muscle endurance, abdominal muscle strength and balance have a relationship with archery achievement.
\end{abstract}

KEYWORDS: Archery, Arm Muscle Strength, Arm Muscle Endurance, Abdominal Muscle Strength.

\section{INTRODUCTION}

Archery is a sport that uses a tool called a bow and arrow and a target board that makes the main center, a bow is a tool used to shoot arrows assisted by the elasticity of the bow itself. In this archery sport, bows and arrows are the main tools in the archery process (Jannah, 2017). In addition to health, sport is also a vehicle for making the nation's name proud. From sports, there are many things that must be considered both to improve performance and for physical fitness (Ayu Reza Adzalika, Soegiyanto, 2019).

Archery is a sport that really requires coordination, endurance, strength, flexibility and balance in order to form proper and correct archery techniques (Yachsie, Prasetyo, et al., 2021). In addition, archery is also a sport that requires precise targeting, because the ultimate goal of archery is to shoot arrows at the target as precisely as possible. Thus, one of the fundamental factors needed in archery is consistency that must be carried out continuously during practice and during the match. In addition to constancy, other factors that influence success in archery are the ability to move muscles and physical condition (Sholikhin et al., 2019). When compared with other static sports such as shooting, archery has a difference that lies in the type of muscle movement ability when doing a push.

Physical problems that often arise from archery are the lack of muscle movement control during archery shooting (Manazi, 2013). If the repetition of archery movements is done excessively and uncontrollably, it can cause injury. The injury will be felt in the shoulder which initially feels little by little but if the muscle is also used continuously it will cause problems that are even worse (Hardi et al., 2020). If the archer uses his shoulder stiffly and endures the pain, then the archer's muscles will become weak and unable to perform the archery movement properly. The shoulder will lose muscle stability to perform its function normally.

Each technique in archery represents a stable sequence of movements and is ideal for learning motor control and skills acquired during kinetic and kinematic processes (Nawir, 2011). This aims to maintain the bowstring load towards the anchoring 
Relationship of Arm Muscle Strength, Arm Muscle Endurance, Abdominal Strength and Balance with Arrow Achievement

phase and holding phase in order to properly perform the releasing phase. Because the determination of the sport of archery lies in the releasing phase which is supported by previous archery phases such as the drawing phase and aiming phase. When the archer pushes the bow with the arm in extension which is held statically towards the target, while the other arm provides a pull in pulling the bowstring from the beginning of the drawing phase to the releasing phase it is carried out dynamically on the arm muscles and shoulder muscles (Arisman et al., 2021).

As for the drawing phase, the bow pulling arm contracts isotonic because of the concentric and eccentric movements of the muscles of the upper extremity (Hardi, 2018). Therefore, the arm holding the bow must be maintained or must be maintained for the stability of the muscle activation that occurs when the pulling movement is carried out. Thus, the muscles involved in drawing the bow should receive special attention in the sport of archery because these muscles work very extra in pulling and holding the weight of the bowstring which is quite heavy and takes place repeatedly in a series of archery movements. Therefore, these muscles must have the strength and endurance to be able to carry out the motion of pulling the bowstring which remains consistent and steady in accordance with the axis of motion. The main muscles that must be trained and developed in archery are the shoulder muscles, the pulling fingers muscles, forearm muscles, wrists, abdominal muscles, and trunk muscles (Septiana et al., 2020).

Strength is used when pulling the bowstring. Strength endurance is carried out for continuation or after the archer has made a full pull, i.e. the full pull is maintained for 3-10 seconds. This is what archers do when shooting by releasing repeatedly, it requires strength endurance (Yachsie, Suhasto, et al., 2021). Seeing the phenomena that occurred, the researchers felt the need and were interested in conducting further research on how big the correlation between arm muscle strength, arm muscle endurance, abdominal muscle strength and balance with archery performance.

\section{METHODS}

This study uses the correlation method. Determination of the sample using purposive sampling technique, namely 13 archery athletes in Surakarta. The variables of this study consisted of four independent variables, namely arm muscle strength, arm muscle endurance, abdominal muscle strength and balance. The dependent variable is archery achievement. The data of this study were obtained through tests and measurements. The data analysis technique used correlation analysis with normality, linearity, and hypothesis testing, namely correlation analysis.

\section{RESULTS AND DISCUSSION}

\section{Data Description}

Table 1. Description of Test Result Data

\begin{tabular}{|l|l|l|l|l|l|}
\hline Variable & N & Mean & SD & Max & Min \\
\hline Arm muscle strength & 13 & 13,23 & 16,679 & 60 & 15 \\
\hline Arm muscle endurance & 13 & 45,23 & 10,010 & 56 & 28 \\
\hline Abdominal muscle strength & 13 & 34,54 & 10,301 & 49 & 15 \\
\hline Balance & 13 & 13,08 & 11,221 & 59 & 25 \\
\hline Archery achievement & 13 & 310,77 & 9,444 & 323 & 290 \\
\hline
\end{tabular}

Based on the research data description table above, information can be obtained: a description of the data for the arm muscle strength variable based on the results of research with a sample of 13 athletes obtained an average of 13.23 with a standard deviation of 16,679, the highest score of 60 and the lowest score of 15 . The description of the data for the arm muscle endurance variable based on the results of the study with a sample of 13 athletes obtained an average of 45.23 with a standard deviation of 10,010, the highest score was 56 and the lowest score was 28 . The description of the data for the abdominal muscle strength variable based on the results of the study with a sample of 13 athletes obtained an average of 34.54 with a standard deviation of 10.301 the highest score of 49 and the lowest score of 15. Description of the data for the balance variable based on the results of the study with a sample of 13 athletes obtained an average of 13.08 with a standard deviation of 11.221, the highest score of 59 and the lowest score of 25 . The description of the data for the archery achievement variable based on the results of research with a sample of 13 athletes obtained an average of 310.77 with a standard deviation of 9.444 , the highest score of 323 and the lowest score of 290. 
Relationship of Arm Muscle Strength, Arm Muscle Endurance, Abdominal Strength and Balance with Arrow Achievement

\section{Normality Test}

The normality test of the data in this study used the Liliefors test. The results of the normality test carried out on the test results of arm muscle strength (X1), arm muscle endurance (X2), abdominal muscle strength (X3), balance (X4) and archery achievement $(\mathrm{Y})$ in this study are as follows:

Table 2. Summary of Data Normality Test Results.

\begin{tabular}{|l|l|l|l|l|}
\hline Variable & N & Mean & SD & Sig, \\
\hline Arm muscle strength & 13 & 13,23 & 16,679 & 0,885 \\
\hline Arm muscle endurance & 13 & 45,23 & 10,010 & 0,538 \\
\hline Abdominal muscle strength & 13 & 34,54 & 10,301 & 0,614 \\
\hline Balance & 13 & 13,08 & 11,221 & 0,291 \\
\hline Archery achievement & 13 & 310,77 & 9,444 & 0,921 \\
\hline
\end{tabular}

Based on the results of the normality test carried out on each of these variables, it can be seen that the significance value of the arm muscle strength variable (X1) is 0.885 , arm muscle endurance $(X 2)$ is 0.538 , abdominal muscle strength (X3) is 0.614 , balance $(X 4)$ is 0.291 and archery achievement $(Y)$ of 0.921 . The result of the significance value of each variable is greater than the value of 0.05 , thus the null hypothesis of each variable is accepted. These results indicate that the data from the arm muscle strength test $(\mathrm{X} 1)$, arm muscle endurance $(\mathrm{X} 2)$, abdominal muscle strength (X3), balance (X4) and archery achievement (Y) are normally distributed.

\section{Linearity Test}

The linearity test of the relationship between each predictor, namely: arm muscle strength (X1), arm muscle endurance (X2), abdominal muscle strength (X3), balance (X4) and archery achievement (Y) was carried out with the help of the SPSS application, namely the function "Compare Means". The results of the linearity test are presented in table form as follows:

Table 3. Summary of Linearity Test Results

\begin{tabular}{|l|l|l|l|}
\hline Variable & Sign & Sign Level & Conclusion \\
\hline X1Y & 0,285 & 0,05 & Linear \\
\hline X2Y & 0,358 & 0,05 & Linear \\
\hline X3Y & 0,553 & 0,05 & Linear \\
\hline X4Y & 0,584 & 0,05 & Linear \\
\hline
\end{tabular}

Based on the results of the linearity test, the value of sig. deviation from linearity of arm muscle strength (X1) with archery achievement $(\mathrm{Y})$ is equal to 0.285 , arm muscle endurance $(\mathrm{X} 2)$ with archery achievement $(\mathrm{Y})$ is equal to 0.358 , abdominal muscle strength (X3) with archery achievement $(Y)$ equal to 0.553 , and balance (X4) with archery achievement (Y) equal to 0.584 . The results of the values of the four variables are greater than the 0.05 significance level. These results indicate that there is a significant linear relationship between data on arm muscle strength (X1), arm muscle endurance (X2), abdominal muscle strength (X3) and balance (X4) with archery achievement $(\mathrm{Y})$.

\section{Correlation Analysis}

To find out whether there is a relationship between the independent variables and the dependent variable in the study, a correlation analysis was carried out for each predictor with criteria using product moment analysis. The results of the correlation analysis of these variables are presented in the form of a table as follows: 
Relationship of Arm Muscle Strength, Arm Muscle Endurance, Abdominal Strength and Balance with Arrow Achievement

Table 4. Correlation Analysis of Each Predictor.

\begin{tabular}{|c|c|c|c|c|c|c|}
\hline & & Push Up & Plank & Sit Up & Balance & Achievement \\
\hline \multirow{3}{*}{ Push Up } & Pearson Correlation & 1 &, $938^{* *}$ & $923^{* *}$ & $872^{* *}$ & $890^{* *}$ \\
\hline & Sig. (2-tailed) & &, 000 &, 000 &, 000 &, 000 \\
\hline & $N$ & 13 & 13 & 13 & 13 & 13 \\
\hline \multirow{3}{*}{ Plank } & Pearson Correlation & $938^{* *}$ & 1 & $927^{* *}$ & $899^{* *}$ & $881^{* *}$ \\
\hline & Sig. (2-tailed) &, 000 & &, 000 &, 000 &, 000 \\
\hline & $N$ & 13 & 13 & 13 & 13 & 13 \\
\hline \multirow{3}{*}{ Sit Up } & Pearson Correlation & $923^{* *}$ &, $927^{* *}$ & 1 & $931^{* *}$ & $903^{* *}$ \\
\hline & Sig. (2-tailed) &, 000 &, 000 & &, 000 &, 000 \\
\hline & $N$ & 13 & 13 & 13 & 13 & 13 \\
\hline \multirow{3}{*}{ Balance } & Pearson Correlation & $872^{* *}$ &, $899^{* *}$ & $931^{* *}$ & 1 & $884^{* *}$ \\
\hline & Sig. (2-tailed) &, 000 &, 000 &, 000 & &, 000 \\
\hline & $N$ & 13 & 13 & 13 & 13 & 13 \\
\hline \multirow{3}{*}{ Achievement } & Pearson Correlation & $890^{* *}$ & $881^{* *}$ & $903^{* *}$ & $884^{* *}$ & 1 \\
\hline & Sig. (2-tailed) &, 000 & 000 &, 000 &, 000 & \\
\hline & $N$ & 13 & 13 & 13 & 13 & 13 \\
\hline
\end{tabular}

a. Based on the correlation analysis between arm muscle strength (X1) and archery achievement (Y), a significance value of 0.00 was obtained. With $\mathrm{N}=13$. Significance value $<0.05$. This shows that there is a significant relationship between arm muscle strength (X1) and archery achievement (Y).

b. Based on the correlation analysis between arm muscle endurance (X2) and archery achievement (Y), a significance value of 0.00 was obtained. With $N=13$. Significance value $<0.05$. This shows that there is a significant relationship between arm muscle endurance $(\mathrm{X} 2)$ and archery achievement $(\mathrm{Y})$.

c. Based on the correlation analysis between abdominal muscle strength (X3) and archery achievement (Y), a significance value of 0.00 was obtained. With $N=13$. Significance value $<0.05$. This shows that there is a significant relationship between abdominal muscle strength (X3) and archery achievement $(\mathrm{Y})$.

d. Based on the correlation analysis between balance (X4) and archery achievement (Y), a significance value of 0.00 was obtained. With $N=13$. Significance value $<0.05$. This shows that there is a significant relationship between balance $(X 4)$ and archery achievement $(\mathrm{Y})$.

\section{Multiple Correlation Analysis}

To find out the relationship between the independent variables together with the dependent variable, a multiple correlation analysis was carried out. The results of the multiple correlation analysis of independent variables together with the dependent variable of this study are presented in tabular form as follows:

Table 5. Multiple Correlation Analysis

\begin{tabular}{|l|l|l|l|}
\hline Variable & N & Sig. F Change & R \\
\hline$X 1, X 2, X 3$ and $X 4$ with $Y$ & 13 & 0,002 & 0,921 \\
\hline
\end{tabular}

a. Based on the results of the double correlation calculation of arm muscle strength (X1), arm muscle endurance (X2), abdominal muscle strength $(\mathrm{X} 3)$ and maximum oxygen volume $(\mathrm{X} 3)$ with archery achievement $(\mathrm{Y})$, the sig $\mathrm{F}$ change value is $0.002<0,05$. This shows that there is a simultaneous correlation or relationship between arm muscle strength (X1), arm muscle endurance (X2), abdominal muscle strength (X3) and balance (X4) with archery achievement (Y).

b. Based on the results of multiple correlation calculations, the $R$ value is 0.921 . Therefore, it can be concluded that there is a degree of perfect category relationship between arm muscle strength (X1), arm muscle endurance (X2), abdominal muscle strength (X3) and balance (X4) with archery achievement (Y). 
Relationship of Arm Muscle Strength, Arm Muscle Endurance, Abdominal Strength and Balance with Arrow Achievement

\section{CONCLUSION}

There is a significant relationship between arm muscle strength, arm muscle endurance, abdominal muscle strength, balance and archery achievement, with an $\mathrm{R}$ value of 0.921 . These results indicate that there is a perfect category relationship between arm muscle strength (X1), arm muscle endurance (X2), abdominal muscle strength (X3) and balance (X4) on archery achievement (Y). The results of this study indicate that arm muscle strength, arm muscle endurance, abdominal muscle strength and balance have a significant relationship with archery achievement. It can be concluded that arm muscle strength, arm muscle endurance, abdominal muscle strength and balance have a relationship with archery achievement.

\section{REFERENCES}

1) Arisman, A., Dlis, F., \& Antoni, R. (2021). Self-check style dalam meningkatkan teknik aiming panahan. Jurnal Olahraga Pendidikan Indonesia (JOPI), 1(1). https://doi.org/10.54284/jopi.v1i1.2

2) Ayu Reza Adzalika, Soegiyanto, R. (2019). Evaluasi Pembinaan Prestasi Atlet Cabang Olahraga Terukur (Atletik, Angkat Besi, Panahan dan Renang) Di Provinsi Lampung. Journal of Physical Education and Sport, 8(1), 56-61.

3) Hardi, V. J. (2018). Frekuensi Latihan Push Up Menggunakan Tumpuan Jari-Jari Tangan Dalam Meningkatkan Kekuatan Otot Pada Teknik Anchoring Cabang Olahraga Panahan. Jurnal Kepelatihan Olahraga, 10(1).

4) Hardi, V. J., Budiman, A., \& Riyadi, I. (2020). Tingkat percaya diri atlet panahan Cimahi Mandiri Archery Club. JPOE, 2(2). https://doi.org/10.37742/jpoe.v2i2.61

5) Jannah, M. (2017). Kecemasan dan Konsentrasi Pada Atlet Panahan. Jurnal Psikologi Teori Dan Terapan.

6) Manazi, F. N. (2013). Pengaruh Penerapan Latihan Imagery Terhadap Hasil Tembakan Pada Jarak 30 Meter Ekstrakurikuler Olahraga Panahan Smp Negeri 02 Bakung Blitar. Jurnal Pendidikan Olahraga Dan Kesehatan, 1(2).

7) Nawir, N. (2011). Kontribusi Kekuatan Otot Tangan Dan Daya Tahan Otot Lengan Dengan Kemampuan Memanah Jarak 30 Meter Pada Atlet Panahan Sulawesi Selatan. Jurnal Pendidikan Kepelatihan Olahraga, 2(3).

8) Septiana, L., Widiyanto, W., \& Wali, C. N. (2020). Analisis Gerak Teknik dan Performa Memanah Nomor 70 Meter Recurve Atlet PPLP Panahan Daerah Istimewa Yogyakarta. Media Ilmu Keolahragaan Indonesia, 10(2). https://doi.org/10.15294/miki.v10i2.25777

9) Sholikhin, Nurkholis, N., \& Jannah, M. (2019). Pengaruh Latihan Progresive Muscle Relaxation dan Imagery Terhadap konsentrasi, kecemasan, dan ketepatan memanah. Jendela Olahraga, 4(1).

10) Yachsie, B. T. P. W. B., Prasetyo, Y., \& Hita, I. P. A. D. (2021). The relation between confidence level towards archery ability at 50 meters distance on archery atheletes. MEDIKORA, 20(1). https://doi.org/10.21831/medikora.v20i1.35916

11) Yachsie, B. T. P. W. B., Suhasto, S., Arianto, A. C., \& Kurniawan, I. L. A. (2021). Keterkaitan konsentrasi dengan akurasi panahan. Multilateral : Jurnal Pendidikan Jasmani Dan Olahraga, 20(2).

https://doi.org/10.20527/multilateral.v20i2.10556 